Bull. Fac .Agric., Cairo Univ. 67: 72-85(2016).

\title{
EFFECT OF SOME NATURAL STIMULANTS ON FRUIT SET,YIELD AND FRUIT QUALITY OF COSTATA PERSIMMON AT HARVEST AND AFTER COLD STORAGE
}

\author{
(Received: 1.2.2016)
}

\author{
By \\ H. El-Zayat, N. M. Taha, N.H. Shakweer and G. A. M. El-Hadidy \\ Horticulture Research Institute, Agriculture Research Center ,Giza, Egypt.
}

\begin{abstract}
This research work was carried out in 2013 and 2014 seasons on "Costata" persimmon trees at Kafr Ashma farm (Menoufeya Governorate),to test the effectiveness of foliar sprays of some stimulants (Ascopin, $\mathrm{GA}_{3}$, Glycine, Chitosan, Azolla, Yeast and Kaolin), on tree yield parameters and fruit quality of fruits, especially tannin content. Each treatment was carried out on a separate row of 10 trees. Five monthly sprays were applied starting from 2 weeks after full bloom (mid April), till mid August. Application of these stimulants had good and variable effects, as they caused a significant increase in fruit set $\%$, number of fruits/tree, yield, fruit weight, dimensions, TSS, acidity, TSS/acidity and firmness compared to the control. Samples of fruits at maturity were picked and placed 4 weeks at $4{ }^{\circ} \mathrm{C}$, and $90 \mathrm{RH}$ and their quality criteria were estimated weekly. Chitosan, Azolla and Yeast achieved the best results in this respect. Yeast treatment resulted in the least content of tannins during fruit growth at harvest and after cold storage, but Ascopin had no positive effect on other quality attributes contrary to the noticeable effects of Chitosan, $\mathrm{GA}_{3}$, Azolla and Yeast on increasing T.S.S. \% vitamin $\mathrm{C}$, and on decreasing acidity $\%$ of fruits and decreasing their weight loss after storage. Fruits from Yeast treatment had the best taste . It is recommended to use any of these stimulants on persimmon orchard, especially Yeast, $\mathrm{GA}_{3}$. Azolla and preferably Yeast, because it is highly effective in getting high yield and reducing tannins as well as being a cheap natural material.
\end{abstract}

Key words: costata persimmon, natural stimulants, tannins.

\section{INTRODUCTION}

Japanese persimmon (Dispyros Kaki L.) is a deciduous fruit belongs to the family Ebenaceae. It originated in China. Its production in Egypt amounts to 14207 tons and the total area is 2029 Feddens according to The Ministry of Agriculture (2013).

Costata is the widely spread persimmon cultivar in Egypt, astringent in taste and should be subjected to post harvest treatments to get rid of the astringency. Any treatments that decrease tannins which cause the astringency of fruits, during their growth on the tree will be very helpful in enhancing the quality of fruits and avoiding costly post harvest treatments. Trying to break the cycle of tannin synthesis in persimmon fruits can be achieved by limiting one or more enzyme activity of this cycle. Astringency is caused by tannins (condensed tannins) molecules, which belong to polyphenols tannins) molecules, which belong to polyphenols, and precisely to phoanthocyanidias.
These latter compounds are a type of oligomers that are synthesized through the shikmic acid pathway (flavonoid pathway). Many enzymes act and intervene to stimulate the reactions leading to tannins synthesis, such as polyphenol oxydase (PPO), which is known also as tyrosinase, polyphenol, phoenolase, catechol oxidase or catecholase. The inhibition of polyphenol oxydase (PPO) may be a good approach to decrease tannins contents in persimmon fruit (York and Marshall, 2003).

There are many inhibitors of this enzyme like ascorbic acid, citric acid, amino acids, such as cysteine found in yeast, which are used to decrease tannins level (Arpita et al., 2010).

Many substances are adopted to increase fruit trees productivity and decrease tannins in fruits, such as plant growth regulators like gibberelic acid $\left(\mathrm{GA}_{3}\right)$. Eliwa et al. (1998) reported that Costata trees sprayed with 100 ppm GA3 scored the highest increment in fruit weight and volume. Also they recorded the highest 
increment in fruit firmness, while TSS, acidity and tannins of fruits were not clearly affected by GA3. In addition, (Kabeel, 1999) reported that Costata persimmon trees sprayed with GA3 at 50, $100 \mathrm{ppm}$ increased fruit set, yield and improved physical and chemical fruits quality.

Chitosan is produced from chitin and has become an important source of biofungicides owing to its non-toxic. In these procedures, Chitosan has been reported to maintain the quality of fruit by avoiding moisture and aromas loss, reducing respiration rates, ethylene production and transpiration. In addition, it inhibits the oxygen penetration to the plant tissue or microbial growth (El-Gaouth et al., 1992 ; Du et al., 1998, Li and Yu 2000 and Jianglian and Shaoying 2013).

Ascopin is a mixture of ascorbic $\left(\mathrm{C}_{6} \mathrm{H}_{8} \mathrm{O}_{6}\right)$ and citric acids $\left(\mathrm{C}_{6} \mathrm{H}_{8} \mathrm{O}_{7}\right)$, which plays an important role in delaying senescence of cells, as well as enhancing fruit growth. Antioxidant Ascopine at 0.1- $0.4 \%$ sprayed on mango, at the low level improved yield, whereas at the high concentrations affected all fruit quality attributes when compared with untreated control. (Mansour et al., 2010). Ibrahim et al. (2007) reported that spraying $500 \mathrm{ppm}$ of both ascorbic and citric acids on mango trees resulted in improving nutritional status of trees, causing high yield and fruit quality.

As for Glycine (one oliphatic amino acid), Fayek et al. (2011) reported that foliar spray of glycine on "Le Conte" pears (1 gm) resulted in the highest significant number of flowers /spur and increased fruit set and yield compared to control.

Another interesting biostimulant is Azolla, a genus of small fast growing aquatic ferns that is in a symbiotic association with nitrogen fixing cyanabacterium. Anabaena Azolla is greater (1618 times) in its ability of $\mathrm{N}_{2}$ fixing than that of free-living Anabaena Cylindrica (Vankatarman, 1981). Also Azolla, is used successfully as a biofertilizer and its beneficial effects are extended to the release of hormones, vitamins and growth promoting substance (Wagner 1997).

Yeast is considered a natural and safe biofertilizer on many crops. The possibility of using yeast was mentioned by some research workers as Mansour (1998) with Anna apples and Attala et al. (2000) with pear trees, Eissa et al., (2003) with apricot, and Ismail et al., (2003) with Thompson seedless grape. Mohamed et al. (2012) reported that yeast application on "Costata" persimmon improved fruit set, yield, fruit weight and fruit juice TSS, while fruit tannins were decreased.

Kaolin clay is a white fine grained aluminum silicate mineral that easily disperses in water. It is used to protect plants from sun burn and heat stress. It emerged as the most important film resource for leaves and fruits used for reflecting radiation, especially UV wave lengths and increased $\mathrm{CO}_{2}$ assimilation reduce transpiration and increase plant water potential, leaf relative water content and stomata resistance in mid day (Wand et al., 2006 and Burme et al., 2011). Also, Aly et al. (2010) cleared that kaolin clay sprayed at $\%, 2 \%$ and $3 \%$ significantly increased leaf area, high positive leaf and fruit contents of $\mathrm{N}, \mathrm{Ca}, \mathrm{Mg}$ while it did not effect firmness, length and diameter of fruits. Kaolin seemed to increase fruit weight, yield and delayed maturation so that this decrease TSS, total sugars and increase acidity and starch content. Moreover, Ergun (2012), reported that kaolin maintained quality during cold storage of "Galaxy" apples.

The scope of this investigation was to raise the productivity, quality and storability to assess the impact of 7 foliar applications on yield and quality attributes at harvest and after cold storage of Costata persimmon.

\section{MATERIAL AND METHODS}

This study was conducted through 2013 and 2014 seasons at Kafr Ashma orchard, the Ministry of Agriculture, Egypt. Trees were planted at $5 \times 5 \mathrm{~m}$ apart in clay soil, under flood irrigation and treated with normal practices recommended by the Ministry of Agriculture. The following treatments were applied as foliar sprays, starting from full bloom (mid April) and continued every month till mid August.

\subsection{The treatments}

1- Ascopin: organic acids (citric + ascorbic acid) in a solution $(5 \mathrm{gm}+5 \mathrm{gm} /$ liter $)$, at a concentration of $1 \%$. This product was imported from the Ministry of Agriculture, General Organization for Agr. Equaliztion Fund "Biofertilizer Unit".

2- Gibberellic acid $\left(\mathrm{GA}_{3}\right): 10 \mathrm{gm} / 201$ water, a synthetic hormone.

3- Glycine: Glycocoll $99.0 \%\left(\mathrm{NH}_{2} \mathrm{CH}_{2} \mathrm{COOH}\right)$ $\mathrm{Cu} 0.02 \%-\mathrm{Pb} 0.01 \%-\mathrm{SO}_{4} 0.005 \%-\mathrm{Ni}$ $0.005 \%$ - Fe $0.005 \%$ - Ca $0.002 \%$ - Na 0.2 $\%$, at a concentration of $100 \mathrm{ppm}$.

4- Chitosan: A high molecular weight of Poly(1.4-B-D glucopyranosamine); 2-Amino-2deoxy-(1->4)-B-D-glucopyranan, applied at $250 \mathrm{ppm}$. 
5- Azolla extract 1 1/ 201 water (5\%): Azolla pinnata aquatic ferns grown in the green house were collected and incorporated into $0.01 \%$ mercuric chloride for 1 mint. and washed for several times, crushed and blended till obtaining a suspension that was filtered and the obtained filtrate was used as foliar spray.

6- Yeast extract at $2 \%$ : The dry pure yeast (Saccharomycess cerevisiae) powder was activated using $10 \mathrm{gm}$ sucrose overnight before spraying on trees.

7- Kaolin: $\mathrm{Al}_{2} \mathrm{Si}_{2} \mathrm{O}_{5}(\mathrm{OH})_{4}$ added as foliar application (natural mineral) used at $0.1 \%$ imported from Marwan Co. for Chemicals.

8- Control: check trees were sprayed with tap water.

Four trees were selected for each treatment and four branches were labeled at four trees direction.

\subsection{The following determinations were measured}

\subsubsection{Fruit set percentage and yield:-}

The percentage of fruit set was calculated by counting the number of flowers of full bloom on mid April and the number of fruit set on mid May on the selected branches. Before harvest, the number of fruits per branch was counted and the number of fruits per tree for determined yield at the harvest time in the both seasons as $\mathrm{kg} / \mathrm{tree}$.

Yield $=$ No. of fruits/tree $*$ Average weight of fruits

\subsubsection{Fruit quality}

Fruits were picked at maturity stage on the $1^{\text {st }}$ week of September according to (El-Badawy 2007), forty fruits were selected from each treatment to evaluate quality parameters, to determine fruit weight $(\mathrm{g})$, dimensions $(\mathrm{cm})$, shape index, fruit firmness was determined by using a modern texture analyzer instrument. The results were expressed as a resistance force of the skin or flesh $\left(\mathrm{gm} / \mathrm{cm}^{2}\right)$.

2.2.2.1. Juice total soluble solids \%, juice acidity and TSS/acidity ratio: TSS \% in fruit juice was determined by refractometer according to A.O.A.C. (1990), and Total acidity (\%) was determined as malic acid according to A.O.A.C. (1990).

2.2.2.2. Tannins content $(\mathrm{mg} / 100 \mathrm{ml}$ juice): A monthly estimation of tannins content during the season after set till harvest according to Winton and Winton (1958).

2.2.2.3. Ascorbic acid contents (V.C) (mg/100 $\mathbf{c m}^{3}$ ): Determined by using dye 2,6dichlorophenyl indophenols method (A.O.A.C. 1990).
2.2.3.Storability Studies: after harvest, samples of the picked fruits were stored (at $4{ }^{\circ} \mathrm{C}$ and $\mathrm{RH}$ 90-95) for 1 month, and four consecutive weekly, samples of fruits were taken to determine the quality attributed of the fruit during the storage process.

\subsubsection{Assessed parameters}

\subsubsection{Tannins content $(\mathrm{mg} / 100 \mathrm{ml}$ juice)} weekly estimation at harvest till the end of the cold storage according to Winton and Winton (1958).

2.2.4.2. The weight loss $(\%)$ calculated as the difference between fruit weight at the start of storage and the weight at the end of the storage process.

Weight loss $\%=\frac{A-B}{A} \times 100$

$A=$ the initial weight

$\mathrm{B}=$ Weight at inspection date.

2.2.4.3. Fruit firmness, Vitamin $C$ content, TSS \%, Acidity \% (A.O.A.C. 1990).

2.2.4.4. Peel color $(\mathrm{cm})$ (Hue angle) of fruit: were determined at harvest, after 2,3 and 4 weeks for detecting the changes during the cold storage period, by using a hunter colorimeter type (DP-9000) for the estimation of a, b and hue angle ( $\mathrm{h} *$ ), as described by McGuire (1992).

2.2.4.5. The panel test: After the cold storage the panel test of fruits was used for judging the cutting quality of fruits of each treatment. A scale of 4 grades was used to evaluate the eating quality. Excellent (10-8.5), V. good (8.4-7), good (6.9-5), poor (unacceptable) (less than 5).

\subsubsection{The statistical analysis}

The obtained data were subjected to analysis of variance (ANOVA) according to (Snedecor and Cochran 1972) by using. Mstat-c program. Duncan test was adopted to compare between means of at (0.05) treatments according to (Waller and Duncan 1969).

\section{RESULTS AND DISCUSSION}

\subsection{Fruit set and yield parameters}

\subsubsection{Fruit set percentage}

It is clear from Table (1) that all the treatments had positive effects, on increasing fruit set $\%$, compared with the control which attained the least fruit set average percentages amounting to $51.23 \%$ in the $1^{s t}$ season and 33.4 $\%$ in the $2^{\text {nd }}$ season. Ascobin in the $1^{\text {st }}$ season and all the treatments except Glycine and Chitosen produced significantly the highest percentages of fruit setting than the rest of treatments and control. Wally et al. (1999) 
Table (1): Effect of the used treatments on fruit set, fruit weight, yield and No. of fruits/tree in "Costata" persimmon fruit during 2013 and 2014 seasons.

\begin{tabular}{|c|c|c|c|c|c|c|c|c|}
\hline \multirow{2}{*}{ Treatments } & \multicolumn{3}{|c|}{ Fruit set $(\%)$} & \multicolumn{2}{|c|}{ No. of fruits/tree } & \multicolumn{2}{c|}{ Yield (kg./tree) } & $\begin{array}{c}\text { Fruit weight at harvest } \\
(\text { g.) }\end{array}$ \\
\cline { 2 - 10 } & $\mathbf{1}^{\text {st }}$ season & $2^{\text {nd }}$ season & $\mathbf{1}^{\text {st }}$ season & $2^{\text {nd }}$ season & $\mathbf{1}^{\text {st }}$ season & $2^{\text {nd }}$ season & $\mathbf{1}^{\text {st }}$ season & $2^{\text {nd }}$ season \\
\hline Ascobin & $77.55 \mathrm{a}$ & $71.8 \mathrm{ab}$ & $270.0 \mathrm{~d}$ & $270.4 \mathrm{e}$ & $26.33 \mathrm{c}$ & $26.8 \mathrm{~b}$ & $97.33 \mathrm{c}$ & $100.2 \mathrm{~cd}$ \\
\hline GA $_{\mathbf{3}}$ & $71.5 \mathrm{~b}$ & $76.53 \mathrm{a}$ & $287.3 \mathrm{~b}$ & $287.1 \mathrm{c}$ & $28.2 \mathrm{bc}$ & $27.87 \mathrm{~b}$ & $98.4 \mathrm{c}$ & $99.33 \mathrm{~d}$ \\
\hline Glycine & $54.87 \mathrm{e}$ & $63.63 \mathrm{c}$ & $223.5 \mathrm{f}$ & $257.8 \mathrm{f}$ & $23.47 \mathrm{~d}$ & $28.67 \mathrm{~b}$ & $101.2 \mathrm{bc}$ & $110.6 \mathrm{~b}$ \\
\hline Chitosan & $60.33 \mathrm{~d}$ & $68.5 \mathrm{c}$ & $228.7 \mathrm{e}$ & $305.1 \mathrm{a}$ & $27.57 \mathrm{c}$ & $36.03 \mathrm{a}$ & $114.7 \mathrm{a}$ & $119.1 \mathrm{a}$ \\
\hline Azolla & $68.4 \mathrm{bc}$ & $75.65 \mathrm{a}$ & $320.3 \mathrm{a}$ & $299.6 \mathrm{~b}$ & $37.37 \mathrm{a}$ & $35.33 \mathrm{a}$ & $116.9 \mathrm{a}$ & $120.0 \mathrm{a}$ \\
\hline Yeast & $69.9 \mathrm{bc}$ & $73.52 \mathrm{ab}$ & $269.8 \mathrm{~d}$ & $280.0 \mathrm{~d}$ & $27.87 \mathrm{bc}$ & $27.9 \mathrm{~b}$ & $103.3 \mathrm{bc}$ & $99.67 \mathrm{~d}$ \\
\hline Kaolin & $65.0 \mathrm{~cd}$ & $77.37 \mathrm{a}$ & $276.5 \mathrm{c}$ & $253.8 \mathrm{f}$ & $29.73 \mathrm{~b}$ & $26.93 \mathrm{~b}$ & $107.0 \mathrm{bc}$ & $106.3 \mathrm{bc}$ \\
\hline Control & $51.23 \mathrm{e}$ & $33.4 \mathrm{~d}$ & $222.1 \mathrm{f}$ & $235.2 \mathrm{~g}$ & $18.87 \mathrm{e}$ & $21.43 \mathrm{c}$ & $86.3 \mathrm{~d}$ & $90.0 \mathrm{e}$ \\
\hline
\end{tabular}

Means in the same column followed by the same letter $(s)$ are not significantly $(p \geq 0.05)$ different.

attained similar results by using $\mathrm{GA}_{3}$ alone or combined with the biozyme and ended in a higher fruit set of "Costata" persimmon (more than $60 \%$ compared with control $36 \%$ ). The results of this experiment are also supported by the data of Kassem et al. (2010) as yeast and gibberellic acid foliar spays had best fruit set with regard to the retention of fruits before June drop than the other treatments.

\subsubsection{Number of fruits per tree}

Data of Table (1) showed that Azolla treatment resulted in significantly the highest number of fruits per tree with significant differences in 2013 season (320.3 fruits/tree) and Chitosan in 2014 season (305.1, fruits/tree) than other treatments and the control which recorded the least number of fruits per tree (222.1 and 235.2) at $1^{\text {st }}$ and the $2^{\text {nd }}$ seasons, respectively.

\subsubsection{Yield (kg/ tree)}

Azolla treatment recorded the highest significant yield/tree in both seasons (37.37 and $35.33 \mathrm{~kg} / \mathrm{tree}$. Chitosan in the second season only had a statistically equal effect (36.03 $\mathrm{kg} /$ tree). the control treatment trees had significantly the least yield.

Our results are also in agreement with those of Mohamed et al. (2013) as using Azolla,which gave the best yield of orange when the trees were treated with Azolla, combined with magnetite as a biofertilizer compared to other treatments and the control.

\subsubsection{Fruit weight at harvest (gm)}

In both seasons, Azolla and Chitosan treatments yielded significantly the highest fruit weight, followed by the other treatments (in the range of 97.5-118 gm) while the control resulted in the least significant fruit weight (86.3$90.0 \mathrm{gm}$ ) in both seasons.

\subsection{Fruit quality attributes in the preharvest stage}

\subsubsection{Fruit dimensions}

Data in Table (2) cleared that Azolla treated fruits attained statistically the longest fruits in both seasons $(6.93$ and $5.83 \mathrm{~cm})$. The effect of both Kaolin and Chitosan was statistically similar in the second season only.

As for the fruit diameter, the significantly widest fruits were attributed to Glycine, Chitosan Azolla and Kaolin in the first season, and only Kaolin treatment in the second. As for the shape index, it was significantly increased only by Azolla treatment and significantly decreased by Glycine treatment compared with the control in the first season only. In the second season however, non of the adopted treatments altered this index significantly (in the range of 1.00 and 0.95 )

\subsubsection{Fruit firmness}

$\mathrm{GA}_{3}$ treatment induced the highest significant firmness recording (25.91 and $26.87 \mathrm{Lb} / \mathrm{inch}^{2}$ ) for the $1^{\text {st }}$ and the $2^{\text {nd }}$ seasons, respectively. Whereas the control fruits attained significantly the lowest firmness.

This phenomenon may be due to the fact that $\mathrm{GA}_{3}$ delays fruit maturity and maintain firmness. Fathi et al. (2011) reported that GA3 in preharvest application at $125 \mathrm{ppm}$ delayed maturity from 17 to 20 days on "Costata" persimmon. Yeast treatment followed with significant differences $(25.43$ and 26.22 Lb/inch ${ }^{2}$.

\subsubsection{TSS $\%$ and acidity $\%$ in Juice}

Data in Table (3) showed that, yeast treatment induced significantly the highest juice TSS $\%$, in the $1^{s t}$ season the $(22.83 \%)$ which was significantly higher than other treatments and The control (19.87\%). GA3 and Azolla treatments came next (22.61 and 22.33) with 
Table (2): Effect of the used treatments on fruit length, diameter (cm), fruit shape index and fruit firmness in "Costata" persimmon fruit immediately after harvest in both 2013 and 2014 seasons.

\begin{tabular}{|c|c|c|c|c|c|c|c|c|}
\hline \multirow{2}{*}{ Treatments } & \multicolumn{2}{|c|}{ Fruit length $(\mathbf{c m})$} & \multicolumn{2}{|c|}{ Fruit diameter (cm) } & \multicolumn{2}{|c|}{ Shape index } & \multicolumn{2}{|c|}{$\begin{array}{c}\text { Firmness } \\
\left(\text { Lb/inch }^{2}\right)\end{array}$} \\
\hline & $1^{s t}$ season & $2^{n d}$ sea & $\begin{array}{c}1^{s t} \\
\text { season }\end{array}$ & $\begin{array}{c}2^{n d} \\
\text { season }\end{array}$ & $1^{\text {st }}$ season & $2^{\text {nd }}$ season & $\mathbf{1}^{s t}$ season & 2 \\
\hline & $5.93 \mathrm{~b}$ & $533 \mathrm{~cd}$ & $5.93 b c$ & $5.33 c$ & $1.00 \mathrm{~b}$ & 1.00 & $23.70 \mathrm{f}$ & $24.63 \mathrm{~g}$ \\
\hline $\mathbf{G A}_{3}$ & $83 \mathrm{~b}$ & $7 \mathrm{~d}$ & $5.83 \mathrm{c}$ & $5.27 \mathrm{c}$ & $\mathrm{b}$ & $1.00 \mathrm{a}$ & $5.91 \mathrm{a}$ & $6.87 \mathrm{a}$ \\
\hline Glycint & $5.73 b c$ & & 6. & $5.73 b$ & 0 & $v$ & $4.70 \mathrm{~d}$ & $6 e$ \\
\hline Chi & 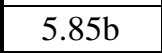 & $5.67 \mathrm{ab}$ & 6. & $5.74 b$ & 0.93 & $a b$ & $4.20 \mathrm{e}$ & $.26 \mathrm{f}$ \\
\hline Azolla & Ja & $\mathrm{a}$ & $6.20 \mathrm{a}$ & $5.87 \mathrm{ab}$ & 1.1 & $a b$ & $25.00 \mathrm{c}$ & $.73 d$ \\
\hline Yeast & $5.57 \mathrm{bc}$ & $5.50 \mathrm{bc}$ & $5.93 b c$ & $5.70 \mathrm{~b}$ & $0.94 \mathrm{~cd}$ & $0.96 \mathrm{ab}$ & $25.43 b$ & $6.22 b$ \\
\hline Kaolin & $5.80 \mathrm{bc}$ & $5.63 \mathrm{ab}$ & $6.08 \mathrm{ab}$ & $5.93 a$ & $0.95 b-d$ & $0.95 \mathrm{~b}$ & $21.68 \mathrm{~g}$ & $25.91 \mathrm{c}$ \\
\hline Control & $5.40 \mathrm{c}$ & $5.23 \mathrm{~d}$ & $5.50 \mathrm{~d}$ & $5.32 \mathrm{c}$ & $0.98 \mathrm{bc}$ & $0.98 \mathrm{ab}$ & $19.86 \mathrm{~h}$ & $24.17 \mathrm{~h}$ \\
\hline
\end{tabular}

Means in the same column followed by the same letter $(s)$ are not significantly $(\mathrm{p} \geq 0.05)$ different.

Table (3): Effect of the used treatments on TSS, acidity and TSS/acid ratio in "Costata" persimmon fruit during both 2013 and 2014 seasons.

\begin{tabular}{|c|c|c|c|c|c|c|}
\hline \multirow{2}{*}{ Treatments } & \multicolumn{2}{|c|}{ TSS } & \multicolumn{2}{c|}{ Acidity } & \multicolumn{2}{c|}{ TSS/acid ratio } \\
\cline { 2 - 7 } & $\mathbf{1}^{\text {st }}$ season & $\mathbf{2}^{\text {nd }}$ season & $\mathbf{1}^{\text {st }}$ season & $\mathbf{2}^{\text {nd }}$ season & $\mathbf{1}^{\text {st }}$ season & $\mathbf{2}^{\text {nd }}$ season \\
\hline Ascobin & $20.87 \mathrm{f}$ & $21.72 \mathrm{f}$ & $0.180 \mathrm{~b}$ & $0.203 \mathrm{bc}$ & $115.9 \mathrm{e}$ & $107.2 \mathrm{e}$ \\
\hline $\mathbf{G A}_{\mathbf{3}}$ & $22.61 \mathrm{~b}$ & $23.59 \mathrm{a}$ & $0.146 \mathrm{c}$ & $0.163 \mathrm{~d}$ & $154.9 \mathrm{~b}$ & $144.7 \mathrm{a}$ \\
\hline Glycine & $21.87 \mathrm{~d}$ & $22.77 \mathrm{~d}$ & $0.170 \mathrm{~b}$ & $0.182 \mathrm{~cd}$ & $128.6 \mathrm{c}$ & $125.1 \mathrm{~b}$ \\
\hline Chitosan & $21.50 \mathrm{e}$ & $22.17 \mathrm{e}$ & $0.180 \mathrm{~b}$ & $0.191 \mathrm{c}$ & $119.4 \mathrm{de}$ & $116.1 \mathrm{c}$ \\
\hline Azolla & $22.33 \mathrm{c}$ & $23.01 \mathrm{c}$ & $0.210 \mathrm{a}$ & $0.222 \mathrm{ab}$ & $106.3 \mathrm{f}$ & $103.6 \mathrm{f}$ \\
\hline Yeast & $22.83 \mathrm{a}$ & $23.39 \mathrm{~b}$ & $0.120 \mathrm{~d}$ & $0.162 \mathrm{~d}$ & $193.3 \mathrm{a}$ & $144.4 \mathrm{a}$ \\
\hline Kaolin & $21.69 \mathrm{de}$ & $22.64 \mathrm{~d}$ & $0.173 \mathrm{~b}$ & $0.201 \mathrm{bc}$ & $125.4 \mathrm{~cd}$ & $112.5 \mathrm{~d}$ \\
\hline Control & $19.87 \mathrm{~g}$ & $20.23 \mathrm{~g}$ & $0.220 \mathrm{a}$ & $0.243 \mathrm{a}$ & $90.30 \mathrm{~g}$ & $83.35 \mathrm{~g}$ \\
\hline
\end{tabular}

Means in the same column followed by the same letter (s) are not significantly $(\mathrm{p} \geq 0.05)$ different.

significant between them and also between yeast treatment . The same trend was observed in the $2^{\text {nd }}$ season with minor difference as GA3 treatment resulted in the highest T.S.S percentage $(23.59 \%)$, followed by yeast and then Azolla treatments with significant differences between them.

The control treatment had the highest significant acidity than other treatments $(0.220$ and $0.243 \%)$ in the $1^{\text {st }}$ season and the $2^{\text {nd }}$ season respectively. Whereas, yeast treatment in both seasons attained statistically the least acidity.

The juice TSS: acid ratio followed the same trend of TSS percentage. Yeast had the highest significant ratio in the $1^{\text {st }}$ season (193.3), while in the $2^{\text {nd }}$ season both GA3 and Yeast had significantly the highest ratios. In all cases, the control fruits had the least ratio.

\subsubsection{Tannins evolution in preharvest stage:-}

Data in Table (4 a) indicated that tannins content (expressed as tannic acid $\mathrm{mg} / 100 \mathrm{ml}$ juice) constantly decreased from a peak value reached approximately at the date of the beginning of the first growth stage in the sigmoid curve of development, (after one month) as cited by Takashi et al. (2010), then started to decrease significantly in the range of $2.5-2.9 \mathrm{mg} / 100 \mathrm{ml}$ juice in both seasons, and this trend of decrease was very pronounced for all treated fruits compared with the control, especially at the end of full growth and immediately before harvest (after 4 months). Fruits of yeast treatment recorded the least tannins value at this stage (after 4 months) in both seasons (1.04 and $1.02 \mathrm{mg}$, respectively), followed by Kaolin treated fruits (1.09 $\mathrm{mg}$ and $1.05 \mathrm{mg}$, respectively), and Azolla treated fruits came after, with 1.25 and $1.15 \mathrm{mg} / 100 \mathrm{ml}$ juice. While the remaining treatments had their tannins content around the values of 1.2 to $1.3 \mathrm{mg} / 100 \mathrm{ml}$ juice in both seasons, compared to the control fruits, with a highest value of tannins $1.9 \mathrm{mg}$ in both seasons. The beneficial effect of yeast in decreasing tannins is explained by its high content of cysteine, an amino acid which acts as a strong inhibitor of polyphenoloxydase, one of the main enzymes in the cycle of tannin synthesis (Cheriot et al.,2007). Shabriar (2013) mentioned that glycine and cysteine inhibited strongly polyphenoloxydase of pears. This result indicates the great usefulness of yeast 
application on persimmon tress, as these fruits are not usually placed in cold storage after harvest.

\subsection{Fruit quality criteria during cold storage} 3.3.1. Tannins content during cold storage

As shown in Table $(4 \mathrm{~b})$, there is a clear decrease in fruit juice tannins from the beginning to the end of cold storage, for all treatments and the control. These results are in agreement with Arnol and Del-Rio (2004). The highest significant tannins mean was recorded for the control fruits in both season $(1.41 \mathrm{mg} / 100$ and $1.2 \mathrm{mg} / 100 \mathrm{ml}$ juice), respectively, while the other treatments proved a clear effect in decreasing tannins content during cold storage. The most clear significant effect was noted for yeast treatment in both seasons with the lowest (0.43 and $0.48 \mathrm{mg} / 100 \mathrm{ml}$ juice). Significant differences were attained will Kaolin treatment in both seasons and Ascobin in the second season only. The results of the interaction of storage period and treatments displayed clearly that the control had the significantly highest tannins content recording 0.87 and $0.70 \mathrm{mg} / 100 \mathrm{ml}$ juice for both seasons, respectively which was significantly higher than all treatments. Effects of all the treatments were statistically equal among the treatments.

\subsubsection{The fruit weight loss (\%) during storage}

Data in Table (5) showed there was a significant increase from one period in cold storage to the following reaching its maximum after 4 weeks of storage. Mean of weight loss percentage of the control fruits was the highest, significantly in the first season $(4.85 \%)$. Whereas, the least weight loss mean was that recorded for both Azolla (1.91\%) and Kaolin $(1.95 \%)$. In the second season, Ascobin treated fruits attained the highest weight loss\% (3.38 $\%$ ), which was significantly higher than the other treatments and the control fruits (3.19\%). Significantly the lowest weight loss mean in the $2^{n d}$ season was that of yeast $(1.61 \%)$.

The analysis of interaction of storage time and that of treatments showed nearly the same increasing trend of weight loss in both seasons as displayed in Table (5). After 4 week of cold storage control had the highest fruit weight loss $(\%)$ in $1^{s t}$ season recording $(6.65 \%)$, and both Kaolin and $\mathrm{GA}_{3}$ recorded the lowest fruit weight loss $(2.96 \%$ and $3.02 \%$, respectively) with significant differences between them. In the second season however, Ascopin fruits had the highest weight loss \% (6.97 \%) which was significantly higher than all the other treatments and the control.
The least significant weight losses $\%$ were due to the yeast, Azolla and Chitosan treatments caused a prolonged maturity phase and that slowed the weight loss of their fruits may be due to less respiration and slower metabolism.

These results are in line with those stated by (Ahmed et al., 2007 and Rao-chandra, 2015).

\subsubsection{Effect of the used treatments on fruit \\ firmness during storage}

The general trend as shown in Table (6) was a gradual significant decrease in firmness during cold storage, which differed significantly among periods of cold storage. On the other side, all the treatments maintained significantly the highest firmness than the control. GA3 treatment fruits had significantly the highest mean of firmness $\left(22.4\right.$ - 23.2) $\mathrm{lb} / \mathrm{inch}^{2}$ for the $1^{\text {st }}$ and the $2^{\text {nd }}$ seasons respectively. Interaction between period of storage and treatments showed that GA3 lost firmness more slowly than other treatments in both seasons and had statistically the highest value of firmness after 4 weeks of cold storage (18.2 and $19.1 \mathrm{Lb} / \mathrm{inch}^{2}$ ), for both the $1^{\text {st }}$ and the $2^{\text {nd }}$ seasons, respectively. Azolla and Yeast followed by the control fruit had the lowest firmness fruits $\left(14.57\right.$ and $15.33 \mathrm{Lb} / \mathrm{inch}^{2}$ at $1^{\text {st }}$ and the second seasons, respectively), with the exception of fruit treated by Glycin at the $2^{\text {nd }}$ season and recorded $12.5 \mathrm{Lb} / \mathrm{inch}^{2}$. Many research articles confirm the effect of GA3 on maintaining fruits firmness after harvest. Ben Arie et al. (1986) mentioned that preharvest spraying of "Triumph" persimmon trees with GA3 retarded the softening rate of GA3 treated fruit during cold storage and after this storage. In another study by Ben Arie et al., (1996), and after examining the cell walls of GA3 treated fruits and control, they concluded that GA3 delayed or inhibited the dissolution of the middle lamella and the separation of the plasmalemma from the cell wall. Ezz et al. (2012) found that the preharvest spray of dry yeast on "Alphons" mangos tree, among other biostimulants caused a significant increase in fruit firmness, (compared to ascorbic acid, citric acid and $\mathrm{Ca} \mathrm{Cl} 2$ treatments).

\subsubsection{Vitamin $C$ content during cold storage}

In the current experiment, there was a major drop in vitamin $\mathrm{C}$ content after 2 weeks in cold storage for all the treatments and this drop continued slowly after 3 weeks in cold store. Ramin and Tabatabaie (2003) mentioned that storing sweet persimmon at $2^{\circ} \mathrm{C}$, resulted in a gradual and noticeable decrease in vitamin $\mathrm{C}$ of this fruit. 
Effect of some natural stimulants on fruit set, yield ..................................................

Table (4a): Effect of the treatments on fruit content of tannins (mg/100 ml juice) in Costata persimmon during preharvest stage.

\begin{tabular}{|c|c|c|c|c|c|}
\hline \multicolumn{6}{|c|}{ Tannins } \\
\hline \multirow{2}{*}{ Treatments } & \multicolumn{4}{|c|}{ pre-harvest } & \multirow{2}{*}{ Mean } \\
\hline & after 1month & after 2month & after 3month & after 4month & \\
\hline \multicolumn{6}{|c|}{$\mathbf{1}^{\text {st }}$ season } \\
\hline Ascobin & $2.57 \mathrm{~b}-\mathrm{d}$ & $2.35 \mathrm{e}-\mathrm{g}$ & $1.95 \mathrm{~h}$ & $1.21 \mathrm{jk}$ & $2.02 \mathrm{C}$ \\
\hline GA3 & $2.62 \mathrm{~b}$ & $2.35 \mathrm{e}-\mathrm{g}$ & $2.05 \mathrm{~h}$ & $1.33 \mathrm{j}$ & $2.09 \mathrm{C}$ \\
\hline Glycine & $2.55 \mathrm{~b}-\mathrm{d}$ & $2.45 \mathrm{c}-\mathrm{e}$ & $2.35 \mathrm{e}-\mathrm{g}$ & $1.28 \mathrm{j}$ & $2.16 \mathrm{~B}$ \\
\hline Chitosan & $2.63 \mathrm{~b}$ & $2.29 \mathrm{fg}$ & $1.95 \mathrm{~h}$ & $1.23 \mathrm{jk}$ & $2.03 \mathrm{C}$ \\
\hline Azola & $2.64 \mathrm{~b}$ & $2.30 \mathrm{e}-\mathrm{g}$ & $1.94 \mathrm{~h}$ & $1.25 \mathrm{j}$ & $2.03 \mathrm{C}$ \\
\hline Yeast & $2.30 \mathrm{e}-\mathrm{g}$ & $1.78 \mathrm{i}$ & $1.25 \mathrm{j}$ & 1.041 & $1.59 \mathrm{E}$ \\
\hline Kaolin & $2.42 \mathrm{~d}-\mathrm{f}$ & $2.25 \mathrm{~g}$ & $1.95 \mathrm{~h}$ & $1.09 \mathrm{kl}$ & $1.93 \mathrm{D}$ \\
\hline Control & $2.92 \mathrm{a}$ & $2.58 \mathrm{bc}$ & $2.45 \mathrm{c}-\mathrm{e}$ & $1.92 \mathrm{~h}$ & $2.47 \mathrm{~A}$ \\
\hline Mean (A) & $2.58 \mathrm{~A}$ & $2.29 \mathrm{~B}$ & $1.99 \mathrm{C}$ & $1.29 \mathrm{D}$ & \\
\hline \multicolumn{6}{|c|}{$2^{\text {nd }}$ season } \\
\hline Ascobin & $2.52 \mathrm{~b}-\mathrm{d}$ & $2.30 \mathrm{ef}$ & $1.90 \mathrm{gh}$ & $1.18 \mathrm{i}-\mathrm{k}$ & $1.98 \mathrm{C}$ \\
\hline GA3 & $2.57 \mathrm{bc}$ & $2.30 \mathrm{ef}$ & $2.00 \mathrm{~g}$ & $1.28 \mathrm{i}$ & $2.04 \mathrm{C}$ \\
\hline Glycine & $2.50 \mathrm{~b}-\mathrm{d}$ & $2.4 \mathrm{c}-\mathrm{e}$ & $2.30 \mathrm{ef}$ & $1.26 \mathrm{i}$ & $2.12 \mathrm{~B}$ \\
\hline Chitosan & $2.59 \mathrm{~b}$ & $2.24 \mathrm{ef}$ & $1.80 \mathrm{~h}$ & $1.20 \mathrm{ij}$ & $1.96 \mathrm{C}$ \\
\hline Azola & $2.59 \mathrm{~b}$ & $2.25 \mathrm{ef}$ & $1.90 \mathrm{gh}$ & $1.15 \mathrm{i}-\mathrm{k}$ & $1.97 \mathrm{C}$ \\
\hline Yeast & $2.25 \mathrm{ef}$ & $1.73 \mathrm{~h}$ & $1.20 \mathrm{ij}$ & $1.02 \mathrm{k}$ & $1.55 \mathrm{E}$ \\
\hline Kaolin & $2.37 \mathrm{~d}-\mathrm{f}$ & $2.20 \mathrm{f}$ & $1.90 \mathrm{gh}$ & $1.05 \mathrm{jk}$ & $1.88 \mathrm{D}$ \\
\hline Control & $2.89 \mathrm{a}$ & $2.52 \mathrm{~b}-\mathrm{d}$ & $2.40 \mathrm{c}-\mathrm{e}$ & $1.89 \mathrm{gh}$ & $2.43 \mathrm{~A}$ \\
\hline Mean (A) & $2.54 \mathrm{~A}$ & $2.24 \mathrm{~B}$ & $1.93 \mathrm{C}$ & $1.25 \mathrm{D}$ & \\
\hline
\end{tabular}

Means in the same column followed by the same letter $(s)$ are not significantly $(\mathrm{p} \geq 0.05)$ different.

Table (4 b): Effect of the treatments on fruit content of tannins (mg/100 ml juice) in Costata persimmon during cold storage of fruit.

\begin{tabular}{|c|c|c|c|c|c|}
\hline \multicolumn{6}{|c|}{ Tannins } \\
\hline \multirow{2}{*}{ Treatments } & \multicolumn{4}{|c|}{ Postharvest } & \multirow{2}{*}{ Mean } \\
\hline & after 1week & after 2 week & after 3week & after 4week & \\
\hline \multicolumn{6}{|c|}{$\mathbf{1}^{s t}$ season } \\
\hline Ascobin & $1.21 \mathrm{~d}$ & $0.35 \mathrm{i}-\mathrm{k}$ & $0.27 \mathrm{j}-\mathrm{m}$ & $0.14 n$ & $0.49 \mathrm{D}$ \\
\hline GA3 & $1.33 \mathrm{e}$ & $0.54 \mathrm{~g}$ & $0.35 \mathrm{i}-\mathrm{k}$ & $0.24 \mathrm{k}-\mathrm{n}$ & $0.62 \mathrm{~B}$ \\
\hline Glycine & $1.28 \mathrm{ed}$ & $0.49 \mathrm{gh}$ & $0.32 \mathrm{i}-1$ & $0.221-n$ & $0.58 \mathrm{BC}$ \\
\hline Chitosan & $1.23 \mathrm{ed}$ & $0.36 \mathrm{i}-\mathrm{k}$ & $0.39 \mathrm{~h}-\mathrm{j}$ & $0.24 \mathrm{k}-\mathrm{n}$ & $0.55 \mathrm{C}$ \\
\hline Azola & $1.25 \mathrm{ed}$ & 0.42 hi & $0.38 \mathrm{~h}-\mathrm{j}$ & $0.25 \mathrm{k}-\mathrm{n}$ & $0.58 \mathrm{BC}$ \\
\hline Yeast & $1.04 \mathrm{e}$ & $0.27 \mathrm{j}-\mathrm{m}$ & $0.221-n$ & $0.19 \mathrm{mn}$ & $0.43 \mathrm{E}$ \\
\hline Kaolin & $1.09 \mathrm{e}$ & $0.30 \mathrm{j}-\mathrm{m}$ & $0.27 \mathrm{j}-\mathrm{m}$ & $0.201-\mathrm{n}$ & $0.47 \mathrm{DE}$ \\
\hline Control & $1.92 \mathrm{a}$ & $1.65 \mathrm{~b}$ & $1.20 \mathrm{~d}$ & $0.87 \mathrm{f}$ & $1.41 \mathrm{~A}$ \\
\hline Mean (A) & $1.29 \mathrm{~A}$ & $0.55 \mathrm{~B}$ & $0.43 \mathrm{C}$ & $0.29 \mathrm{D}$ & \\
\hline \multicolumn{6}{|c|}{$2^{\text {nd }}$ season } \\
\hline Ascobin & $1.18 \mathrm{~cd}$ & $0.33 \mathrm{~g}-\mathrm{i}$ & $0.17 \mathrm{j}-1$ & $0.14 \mathrm{kl}$ & $0.52 \mathrm{CD}$ \\
\hline GA3 & $1.28 \mathrm{bc}$ & $0.42 \mathrm{gh}$ & $0.27 \mathrm{ij}$ & $0.15 \mathrm{kl}$ & $0.62 \mathrm{~B}$ \\
\hline Glycine & $1.26 \mathrm{bc}$ & $0.44 \mathrm{~g}$ & $0.26 \mathrm{ij}$ & $0.15 \mathrm{kl}$ & $0.615 \mathrm{~B}$ \\
\hline Chitosan & $1.20 \mathrm{bc}$ & $0.42 \mathrm{gh}$ & $0.26 \mathrm{ij}$ & $0.15 \mathrm{kl}$ & $0.59 \mathrm{BC}$ \\
\hline Azola & $1.15 \mathrm{c}-\mathrm{e}$ & $0.44 \mathrm{~g}$ & $0.28 \mathrm{~h}-\mathrm{j}$ & $0.15 \mathrm{kl}$ & $0.59 \mathrm{BC}$ \\
\hline Yeast & $1.02 \mathrm{ef}$ & $0.30 \mathrm{~g}-\mathrm{j}$ & $0.21 \mathrm{ij}$ & $0.14 \mathrm{kl}$ & $0.48 \mathrm{D}$ \\
\hline Kaolin & $1.05 \mathrm{de}$ & $0.31 \mathrm{~g}-\mathrm{j}$ & $0.21 \mathrm{ij}$ & $0.14 \mathrm{kl}$ & $0.60 \mathrm{D}$ \\
\hline Control & $1.89 \mathrm{a}$ & $1.33 \mathrm{~b}$ & $0.90 \mathrm{f}$ & $0.7 \mathrm{kl}$ & $1.20 \mathrm{~A}$ \\
\hline Mean (A) & $1.25 \mathrm{~A}$ & $0.50 \mathrm{~B}$ & $0.32 \mathrm{C}$ & $0.215 \mathrm{D}$ & \\
\hline
\end{tabular}

Means in the same column followed by the same letter (s) are not significantly ( $\mathrm{p} \geq 0.05)$ different. 
Table (5): Effect of the used treatments on weight loss (\%) of Costata persimmon fruit after 3 periods in cold storage.

\begin{tabular}{|c|c|c|c|c|c|}
\hline \multirow{2}{*}{ Treatment } & \multicolumn{4}{|c|}{ Weight loss (\%) } & \multirow{2}{*}{ Mean } \\
\hline & Zero time & After 2 weeks & After 3 weeks & After 4 weeks & \\
\hline Ascobin & $0.00 p$ & $2.22 \mathrm{i}$ & $3.04 \mathrm{e}$ & $4.27 \mathrm{c}$ & $3.18 \mathrm{~B}$ \\
\hline $\mathbf{G A}_{3}$ & $0.00 p$ & $1.22 n$ & $1.96 \mathrm{j}$ & $3.02 \mathrm{ef}$ & $2.07 \mathrm{D}$ \\
\hline Glycine & $0.00 p$ & $1.07 \mathrm{op}$ & $2.01 \mathrm{j}$ & $3.19 \mathrm{~d}$ & $2.09 \mathrm{D}$ \\
\hline Chitosan & $0.00 p$ & $1.22 \mathrm{n}$ & $2.01 \mathrm{j}$ & $2.62 \mathrm{~g}$ & $1.95 \mathrm{E}$ \\
\hline Azolla & $0.00 \mathrm{p}$ & $1.03 \mathrm{p}$ & 1.631 & $3.08 \mathrm{e}$ & $1.91 \mathrm{E}$ \\
\hline Yeast & $0.00 p$ & $1.36 \mathrm{~m}$ & $2.42 \mathrm{~h}$ & $3.10 \mathrm{e}$ & $2.29 \mathrm{C}$ \\
\hline Kaolin & $0.00 p$ & $1.12 \mathrm{o}$ & $1.78 \mathrm{k}$ & $2.96 \mathrm{f}$ & $1.95 \mathrm{E}$ \\
\hline Control & $0.00 \mathrm{p}$ & $3.09 \mathrm{e}$ & $1.80 \mathrm{~b}$ & $6.65 \mathrm{a}$ & $4.85 \mathrm{~A}$ \\
\hline Mean & $0.00 \mathrm{D}$ & $1.54 \mathrm{C}$ & $2.45 \mathrm{~B}$ & $3.61 \mathrm{~A}$ & \\
\hline \multicolumn{6}{|c|}{$2^{\text {nd }}$ season } \\
\hline Ascobin & $0.00 \mathrm{n}$ & $1.00 \mathrm{~m}$ & $2.14 \mathrm{~h}$ & $6.97 \mathrm{a}$ & $3.38 \mathrm{~A}$ \\
\hline GA3 & $0.00 \mathrm{n}$ & $1.34 \mathrm{k}$ & $1.98 \mathrm{i}$ & $3.35 \mathrm{~d}$ & $2.22 \mathrm{D}$ \\
\hline Glycine & $0.00 \mathrm{n}$ & $0.99 \mathrm{~m}$ & $1.96 \mathrm{i}$ & $3.30 \mathrm{~d}$ & $2.08 \mathrm{E}$ \\
\hline Chitosan & $0.00 \mathrm{n}$ & 1.181 & $1.92 \mathrm{i}$ & $3.02 \mathrm{ef}$ & $2.04 \mathrm{E}$ \\
\hline Azolla & $0.00 \mathrm{n}$ & $1.08 \mathrm{~lm}$ & $1.98 \mathrm{i}$ & $2.98 \mathrm{f}$ & $2.01 \mathrm{E}$ \\
\hline Yeast & $0.00 \mathrm{n}$ & $1.56 \mathrm{j}$ & $2.39 \mathrm{~g}$ & $2.90 \mathrm{f}$ & $1.61 \mathrm{~F}$ \\
\hline Kaolin & $0.00 \mathrm{n}$ & $1.32 \mathrm{k}$ & $1.95 \mathrm{i}$ & $5.36 \mathrm{~b}$ & $2.88 \mathrm{C}$ \\
\hline Control & $0.00 \mathrm{n}$ & $1.33 \mathrm{k}$ & $3.08 \mathrm{e}$ & $5.14 \mathrm{c}$ & $3.19 \mathrm{~B}$ \\
\hline Mean & $0.00 \mathrm{D}$ & $1.22 \mathrm{C}$ & $2.18 \mathrm{~B}$ & $4.12 \mathrm{~A}$ & \\
\hline
\end{tabular}

Means in the same column followed by the same letter (s) are not significantly ( $p \geq 0.05)$ different

Table (6): Effect of the treatments on fruit firmness (Lb/inch ${ }^{2}$ ) in "Costata" persimmon after 4 periods in cold storage.

\begin{tabular}{|c|c|c|c|c|c|}
\hline \multirow{2}{*}{ Treatments } & \multicolumn{4}{|c|}{ Firmness (Lb/inch $\left.{ }^{2}\right)$} & \multirow{2}{*}{ Mean } \\
\hline & At harvest & After 2weeks & After 3weeks & After 4weeks & \\
\hline \multicolumn{6}{|c|}{$1^{\text {st }}$ season } \\
\hline Ascobin & $23.71 \mathrm{ef}$ & $22.70 \mathrm{hi}$ & $19.08 \mathrm{p}$ & $16.22 \mathrm{u}$ & $20.43 \mathrm{E}$ \\
\hline GA3 & $25.93 \mathrm{a}$ & $23.82 \mathrm{de}$ & 21.751 & $18.22 \mathrm{q}$ & $22.43 \mathrm{~A}$ \\
\hline Glycine & 24.65 be & $22.17 \mathrm{j}-1$ & 19.58 op & $17.05 \mathrm{st}$ & $20.86 \mathrm{D}$ \\
\hline Chitosan & $24.22 \mathrm{~cd}$ & $21.91 \mathrm{kl}$ & 19.32 op & $16.83 \mathrm{t}$ & $20.57 \mathrm{E}$ \\
\hline Azolla & $24.87 \mathrm{~b}$ & $22.56 \mathrm{~h}-\mathrm{j}$ & $20.23 n$ & $17.41 \mathrm{ts}$ & $21.27 \mathrm{C}$ \\
\hline Yeast & $25.51 \mathrm{a}$ & $23.05 \mathrm{gh}$ & $20.57 \mathrm{mn}$ & $17.56 \mathrm{r}$ & $21.67 \mathrm{~B}$ \\
\hline Kaolin & $24.52 \mathrm{bc}$ & $22.37 \mathrm{i}-\mathrm{k}$ & 19.72 o & $16.67 \mathrm{yu}$ & $20.82 \mathrm{D}$ \\
\hline Control & $23.26 \mathrm{fg}$ & $20.87 \mathrm{~m}$ & $18.59 \mathrm{q}$ & $14.57 \mathrm{v}$ & $19.32 \mathrm{~F}$ \\
\hline Mean (A) & $24.59 \mathrm{~A}$ & $22.43 \mathrm{~B}$ & $19.85 \mathrm{C}$ & $16.82 \mathrm{D}$ & \\
\hline \multicolumn{6}{|c|}{$2^{n d}$ season } \\
\hline Ascobin & $24.63 \mathrm{e}$ & $22.58 \mathrm{i}$ & $20.12 \mathrm{k}$ & $17.32 \mathrm{q}$ & $21.16 \mathrm{D}$ \\
\hline GA3 & $26.87 \mathrm{a}$ & $24.51 \mathrm{e}$ & $22.37 \mathrm{i}$ & $19.08 \mathrm{~m}$ & $23.21 \mathrm{~A}$ \\
\hline Glycine & $25.46 \mathrm{ed}$ & $23.21 \mathrm{~h}$ & 20.321 & $12.51 \mathrm{~s}$ & $20.38 \mathrm{E}$ \\
\hline \begin{tabular}{|l|} 
Chitosan \\
\end{tabular} & $25.26 \mathrm{~d}$ & $22.12 \mathrm{ij}$ & 20.181 & $17.91 \mathrm{op}$ & $21.37 \mathrm{D}$ \\
\hline Azolla & $25.73 \mathrm{~b}-\mathrm{d}$ & $23.47 \mathrm{gh}$ & $21.51 \mathrm{k}$ & 18.41 no & $22.38 \mathrm{C}$ \\
\hline Yeast & $26.22 \mathrm{~b}$ & $24.26 \mathrm{ef}$ & $21.63 \mathrm{jk}$ & $18.81 \mathrm{mn}$ & $22.73 \mathrm{~B}$ \\
\hline Kaolin & $25.91 \mathrm{bc}$ & $23.87 \mathrm{fg}$ & 20.621 & $17.72 \mathrm{pq}$ & $22.03 \mathrm{C}$ \\
\hline Control & 24.17 ef & $21.42 \mathrm{k}$ & $18.22 \mathrm{op}$ & $15.33 \mathrm{r}$ & $19.78 \mathrm{~F}$ \\
\hline Mean (A) & $25.53 \mathrm{~A}$ & $23.18 \mathrm{~B}$ & $20.62 \mathrm{C}$ & $17.14 \mathrm{D}$ & \\
\hline
\end{tabular}

Means in the same column followed by the same letter $(s)$ are not significantly ( $\mathrm{p} \geq 0.05)$ different. 
Table (7). Effect of the treatments on vitamin $C$ content of fruit in "Costata" persimmon after 3 periods during cold storage.

\begin{tabular}{|l|c|c|c|c|}
\hline \multirow{2}{*}{ Treatments } & \multicolumn{4}{c|}{ Vitamin C } \\
\cline { 2 - 5 } & At harvest & After 2 weeks & After 3 weeks & Mean \\
\hline \multicolumn{5}{|c|}{$\mathbf{1}^{\text {st }}$ season } \\
\hline Ascobin & $17.17 \mathrm{c}$ & $5.93 \mathrm{ef}$ & $4.40 \mathrm{l}$ & $9.17 \mathrm{C}$ \\
\hline GA 3 & $17.27 \mathrm{c}$ & $5.53 \mathrm{~g}$ & $4.00 \mathrm{~m}$ & $8.93 \mathrm{E}$ \\
\hline Glycine & $16.80 \mathrm{~d}$ & $5.80 \mathrm{f}$ & 4.471 & $9.02 \mathrm{DE}$ \\
\hline Chitosan & $16.87 \mathrm{~d}$ & $5.87 \mathrm{ef}$ & $4.67 \mathrm{k}$ & $9.13 \mathrm{CD}$ \\
\hline Azolla & $17.13 \mathrm{c}$ & $5.93 \mathrm{ef}$ & $5.13 \mathrm{i}$ & $9.40 \mathrm{~B}$ \\
\hline Yeast & $17.73 \mathrm{a}$ & $6.07 \mathrm{e}$ & $5.33 \mathrm{~g}-\mathrm{i}$ & $9.71 \mathrm{~A}$ \\
\hline Kaolin & $17.53 \mathrm{~b}$ & $6.00 \mathrm{ef}$ & $5.27 \mathrm{~h} \mathrm{i}$ & $9.60 \mathrm{~A}$ \\
\hline Control & $16.80 \mathrm{~d}$ & $4.57 \mathrm{gh}$ & $4.87 \mathrm{j}$ & $9.04 \mathrm{DE}$ \\
\hline Mean $(\mathbf{A})$ & $17.16 \mathrm{~A}$ & $5.83 \mathrm{~B}$ & $4.77 \mathrm{C}$ & \\
\hline \multicolumn{5}{|c|}{$\mathbf{2}^{\text {nd }}$ season } \\
\hline Ascobin & $17.40 \mathrm{c}$ & $5.93 \mathrm{f}$ & $4.53 \mathrm{k}$ & $9.29 \mathrm{D}$ \\
\hline GA & $16.87 \mathrm{e}$ & $5.67 \mathrm{~g}$ & $4.40 \mathrm{k}$ & $8.98 \mathrm{~F}$ \\
\hline Glycine & $17.27 \mathrm{c}$ & $5.93 \mathrm{~g}$ & $4.73 \mathrm{j}$ & $9.31 \mathrm{D}$ \\
\hline Chitosan & $16.93 \mathrm{de}$ & $5.73 \mathrm{~g}$ & $4.73 \mathrm{j}$ & $9.13 \mathrm{E}$ \\
\hline Azolla & $17.07 \mathrm{~d}$ & $5.93 \mathrm{~g}$ & $5.40 \mathrm{~h}$ & $9.47 \mathrm{C}$ \\
\hline Yeast & $17.93 \mathrm{a}$ & $6.00 \mathrm{f}$ & $5.33 \mathrm{~h}$ & $9.76 \mathrm{~A}$ \\
\hline Kaolin & $17.60 \mathrm{~b}$ & $6.00 \mathrm{f}$ & $5.33 \mathrm{~h}$ & $9.64 \mathrm{~B}$ \\
\hline Control & $17.00 \mathrm{de}$ & $5.47 \mathrm{~h}$ & $5.00 \mathrm{i}$ & $9.16 \mathrm{E}$ \\
\hline Mean $(\mathbf{A})$ & $17.26 \mathrm{~A}$ & $5.83 \mathrm{~B}$ & $4.93 \mathrm{C}$ & \\
\hline
\end{tabular}

Means in the same column followed by the same letter (s) are not significantly $(\mathrm{p} \geq 0.05)$ different.

Data in Table (7) indicated that fruits from trees of Yeast treatment had the highest vitamin $\mathrm{C}$ mean in both seasons and significantly higher than all other treatments $(9.71$ and $9.76 \mathrm{mg} / 100$ $\mathrm{gm}$ at the $1^{\text {st }}$ and the $2^{\text {nd }}$ seasons in a row), while GA3 treatment recorded the lowest mean of vitamin $\mathrm{C}$ in both seasons $(8.93$ and $8.98 \mathrm{mg} /$ $100 \mathrm{gm}$ in the $1^{\text {st }}$ and the $2^{\text {nd }}$ seasons respectively), in a clear indication to the delayed maturity reactions caused by GA3 application.

Interaction of cold storage time and treatments type showed that yeast treatment resulted in significantly higher vitamin $\mathrm{C}$ content after 3 week than all the other treatments in the $1^{s t}$ season (5.33 mg / $\left.100 \mathrm{gm}\right)$ and was among the three substances causing the highest vitamin $\mathrm{C}$ content (Azolla, Yeast and Kaolin with values of $5.4,5.33$ and $5.33 \mathrm{mg} / 100 \mathrm{gm}$ of vitamin $\mathrm{C}$, respectively) in the same period at the $2^{\text {nd }}$ season. GA3 treatment resulted in fruits with the lowest vitamin $\mathrm{C}$ content after 3 weeks in cold storage in both seasons 4.0 and $4.40 \mathrm{mg} / 100 \mathrm{gm}$ in the $1^{s t}$ and the $2^{\text {nd }}$ seasons respectively). Other treatments had intermediate values of vitamin $\mathrm{C}$ in the range of $4.40-4.73 \mathrm{mg} / 100 \mathrm{gm}$ ) but significantly lower than vitamin $\mathrm{C}$ content of control. Jacqueline et al. (2014) cited that preharvest Chitosan application on Raspberry fruits before storage at $0 \% \mathrm{C}$ for 12 days caused a noticeable loss in vitamin $\mathrm{C}$ content by the end of cold storage.

3.3.5. Effect of treatments on total soluble solids (\%) and acidity (\%) during cold storage

3.3.5.1. Total soluble solids (\%):- As shown in Table (8), TSS \% increased significantly in cold storage from one period to another, and reach its maximum by the end of storage after 4 weeks. At the $1^{s t}$ season the highest mean of TSS \% content was that of yeast $(24.42 \%)$ with significant differences if compared with all other treatments, while Azolla mean TSS \% content followed directly with $24 \%$, and the control fruit had the lowest TSS \% content mean $(21.17 \%)$, in $2^{\text {nd }}$ season, Kaolin treatment had the highest TSS \% content mean (24.95\%), and significantly different than all other treatments, followed by yeast TSS \% content mean (24.41\%), while the control had the lowest significant mean of TSS $\%$ content $(21.53 \%)$. The interaction of cold storage period and type of treatments repeated the above mentioned pattern and the highest TSS $\%$ content after 4 week in cold storage was that of yeast at the $1^{\text {st }}$ season and Glycine in the $2^{\text {nd }}$ season, and control TSS \% was the least in both season $(22.53 \%$ and $23.12 \%$ respectively.

Generally, all substances used in this experiment were more effective in boasting trees nutrition and raising photosynthesis activity of 


\begin{tabular}{|c|c|c|c|c|c|c|c|c|c|c|}
\hline \multirow{2}{*}{$\begin{array}{l}\text { Treat- } \\
\text { ments }\end{array}$} & \multicolumn{4}{|c|}{ TSS (\%) } & \multirow[b]{2}{*}{ Mean (B) } & \multicolumn{4}{|c|}{ Acidity (\%) } & \multirow{2}{*}{$\begin{array}{c}\text { Mean } \\
\text { (B) }\end{array}$} \\
\hline & At harvest & $\begin{array}{c}\text { After } 2 \\
\text { weeks }\end{array}$ & $\begin{array}{c}\text { After } 3 \\
\text { weeks }\end{array}$ & $\begin{array}{c}\text { After } 4 \\
\text { weeks }\end{array}$ & & At harvest & $\begin{array}{c}\text { After } 2 \\
\text { weeks }\end{array}$ & $\begin{array}{c}\text { After } 3 \\
\text { weeks }\end{array}$ & $\begin{array}{c}\text { After } 4 \\
\text { weeks }\end{array}$ & \\
\hline \multicolumn{10}{|c|}{$1^{\text {st }}$ season } & \\
\hline \begin{tabular}{|l} 
Ascobin \\
\end{tabular} & 20.87 w & $21.32 \mathrm{v}$ & 22.730 & $23.55 \mathrm{jk}$ & $22.12 \mathrm{G}$ & 0.179 c-f & $0.161 \mathrm{f}-\mathrm{i}$ & 0.142 j-l & 0.133 k-n & $0.154 \mathrm{C}$ \\
\hline GA3 & $22.61 \mathrm{p}$ & 23.211 & $24.72 \mathrm{f}$ & $26.22 \mathrm{~b}$ & 24.19 B & 0.146 i-k & 0.126 l-o & 0.107 p-r & $0.091 \mathrm{r}$ & 0.118 E \\
\hline \begin{tabular}{|l|} 
Glycine \\
\end{tabular} & $21.85 \mathrm{~s}$ & $22.61 p$ & $23.58 \mathrm{ij}$ & $25.13 \mathrm{~d}$ & $23.29 \mathrm{E}$ & 0.167 e-h & 0.142 j-l & 0.117 n-p & 0.106 p-r & $0.133 \mathrm{D}$ \\
\hline \begin{tabular}{|l|} 
Chitosan \\
\end{tabular} & $21.51 \mathrm{u}$ & 22.730 & $23.52 \mathrm{k}$ & $24.21 \mathrm{~h}$ & 23.00 F & 0.182 c-e & 0.167 e-h & 0.147 i-k & $0.1120-q$ & $0.152 \mathrm{C}$ \\
\hline \begin{tabular}{|l} 
Azolla \\
\end{tabular} & $22.13 r$ & $23.52 \mathrm{k}$ & $24.28 \mathrm{~g}$ & $25.88 \mathrm{c}$ & $24.00 \mathrm{C}$ & $0.207 \mathrm{ab}$ & 0.196 bc & 0.172 d-g & 0.150 h-k & $0.181 \mathrm{~B}$ \\
\hline Yeast & $22.81 \mathrm{n}$ & $23.52 \mathrm{k}$ & 24.87 e & 26.46 a & $24.42 \mathrm{~A}$ & 0.141 j-l & 0.122 m-p & 0.106 p-r & 0.097 qr & $0.116 \mathrm{E}$ \\
\hline Kaolin & $21.69 \mathrm{t}$ & $22.95 \mathrm{~m}$ & $23.62 \mathrm{i}$ & $25.13 \mathrm{~d}$ & 23.35 D & 0.176 d-g & $0.159 \mathrm{~g}-\mathrm{j}$ & 0.138 k-m & 0.132 k-n & $0.151 \mathrm{C}$ \\
\hline \begin{tabular}{|l|} 
Control \\
\end{tabular} & $19.87 \mathrm{y}$ & $20.42 \times$ & $21.87 \mathrm{~s}$ & $22.53 \mathrm{q}$ & $21.17 \mathrm{H}$ & 0.221 a & $0.207 \mathrm{ab}$ & $0.187 \mathrm{~cd}$ & $0.162 \mathrm{f}-\mathrm{i}$ & $0.194 \mathrm{~A}$ \\
\hline $\operatorname{Mean}(A)$ & $21.67 \mathrm{D}$ & $22.54 \mathrm{C}$ & 23.67 B & $24.89 \mathrm{~A}$ & & $0.177 \mathrm{~A}$ & 0.160 B & $0.139 \mathrm{C}$ & 0.123 D & \\
\hline \multicolumn{10}{|c|}{$2^{\text {nd }}$ season } & \\
\hline \begin{tabular}{|l|} 
Ascobin \\
\end{tabular} & $21.72 \mathrm{v}$ & $22.97 q$ & $23.61 \mathrm{~m}$ & $25.05 \mathrm{f}$ & 23.34 F & $0.203 \mathrm{~cd}$ & 0.172 g-k & 0.157 k-m & $0.142 \mathrm{~m}-\mathrm{o}$ & $0.168 \mathrm{C}$ \\
\hline GA3 & 23.250 & $3.57 \mathrm{~m}$ & $24.09 \mathrm{k}$ & $25.76 \mathrm{~cd}$ & 24.17 D & $0.163 \mathrm{j}-\mathrm{l}$ & $0.141 \mathrm{~m}-\mathrm{o}$ & $0.121 \mathrm{pq}$ & $0.107 q$ & 0.133 E \\
\hline \begin{tabular}{|l|} 
Glycine \\
\end{tabular} & $22.77 \mathrm{r}$ & $24.28 \mathrm{j}$ & $25.87 \mathrm{c}$ & 27.42 a & $25.09 \mathrm{~A}$ & $0.182 \mathrm{f}-\mathrm{j}$ & 0.163 j-I & 0.147 I-n & 0.132 n-p & $0.156 \mathrm{D}$ \\
\hline \begin{tabular}{|c|} 
Chitosan \\
\end{tabular} & $22.17 \mathrm{t}$ & $23.67 \mathrm{~m}$ & 24.97 f & $25.46 \mathrm{e}$ & $24.07 \mathrm{E}$ & $0.191 \mathrm{~d}-\mathrm{g}$ & 0.183 e-i & 0.166 i-k & $0.142 \mathrm{~m}-0$ & $0.171 \mathrm{C}$ \\
\hline Azolla & $23.01 \mathrm{q}$ & 23.20 op & $24.72 \mathrm{~h}$ & $25.66 \mathrm{~d}$ & 24.15 D & $0.222 \mathrm{~b}$ & 0.202 c-e & 0.187 d-h & 0.173 g-k & $0.196 \mathrm{~B}$ \\
\hline Yeast & $23.39 n$ & 23.871 & $24.82 \mathrm{~g}$ & 25.55 e & $24.41 \mathrm{C}$ & $0.162 \mathrm{kl}$ & $0.141 \mathrm{~m}-\mathrm{o}$ & 0.123 o-q & $0.107 q$ & $0.133 \mathrm{E}$ \\
\hline Kaolin & $22.64 \mathrm{~s}$ & 24.42 i & $25.87 \mathrm{c}$ & 26.89 b & 24.95 B & 0.201 c-e & 0.171 h-k & 0.157 k-m & $0.142 \mathrm{~m}-\mathrm{o}$ & $0.168 \mathrm{C}$ \\
\hline \begin{tabular}{|l|} 
Control \\
\end{tabular} & $20.23 \mathrm{x}$ & 20.91 w & 21.87 u & $23.12 p$ & $21.53 \mathrm{G}$ & $0.243 \mathrm{a}$ & 0.211 bc & 0.193 c-f & 0.172 g-k & $0.205 \mathrm{~A}$ \\
\hline $\operatorname{Mean}(\mathbf{A})$ & $22.40 \mathrm{D}$ & $23.36 \mathrm{C}$ & 24.48 B & $25.61 \mathrm{~A}$ & & 0.196 A & 0.173 B & $0.156 \mathrm{C}$ & 0.140 D & \\
\hline
\end{tabular}

tree leaves with various degrees that was reflected on the total soluble solids \% content of persimmon fruit. Kassem et al. (2010) have indicated that GA3 and Yeast foliar sprays on Costata persimmon resulted in higher TSS \% value, in comparison to other applied biostimulants.

\subsubsection{Fruit acidity (\%)}

As shown in Table (8), acidity \% of fruits juice in all the treatments decreased significantly from one period in cold storage to the following and the maximum drop in acidity was recorded by the end of cold storage (after 4 weeks). Yeast treatment fruits had the least acidity $\%$ mean in both seasons (with $0.116 \% 1^{s t}$ season and 0.133 $\% 2^{\text {nd }}$ season) and this was significantly different than the rest of treatments and the control. GA3 induced a statistically equal effect in the first season only. Control fruits had the highest acidity \% mean in both season, recording 0.194 $\%$ and 0.205 at the $1^{s t}$ and the $2^{\text {nd }}$ seasons in a row. The highest acidity $\%$ mean among the treatments was Azolla in both seasons $(0.181 \%$ and $0.196 \%$ at $1^{\text {st }}$ and the $2^{\text {nd }}$ season respectively).

The interaction of cold storage period and the treatments showed that after 4 weeks of cold storage acidity $\%$ was at its lowest value with yeast and GA3 treatments showing significantly the lowest value (at the $2^{\text {nd }}$ season). Control fruits acidity was significantly higher than all the treated fruits after 4 weeks of cold storage recording $0.162 \%$ in the $1^{\text {st }}$ season and recording with Azolla fruits similar higher values of acidity than other treatments $(0.172 \%$ for control and $0.173 \%$ for Azolla ). Fruits of other treatments had intermediate acidity values. These results are in agreement with the results of Nasr et al., (2009) who stated that GA3 and yeast sprays on "Le-Cont" pears reduced acidity remarkably in comparison with other treatments. These results are also supported by the conclusions of the work of Kassem et al. (2010) who related to Yeast effects, among other foliar sprays on "Costata" persimmon fruits.

\subsubsection{Effect of treatments on peel color of persimmon during cold storage}

As noted from Table (9), there decrease in Hue angle degree (representing the color) during cold storage in the range lying from $90^{\circ}$ to $30^{\circ}$ during persimmon cold storage and that means there was a change of color during cold storage from pale green yellow towards orange red color. Fruit color measurements revealed a maturity delaying effect of GA3, reflected in the slow synthesis of peel pigments as these fruits, which had the highest hue angle $\left(85.5^{\circ}\right.$ - yellow green color) after 2 weeks in cold storage, while all other treatments measurements of color at the same period were too close to each other (on the rang of $61.04^{\circ}-75.9^{\circ}$ ). Ascopin came second after GA3, with the value of $75.9^{\circ}$ hue angle. 
Kaolin induced the best color development of peel $\left(61.4^{\circ}\right)$ after 2 weeks in cold storage. It is to be noted that fruits stayed for 4 weeks in cold storage $\left(4^{\circ} \mathrm{C}\right)$ stimulated synthesis of peel color, irrespective of treatments, indicating a certain effect of the continuity of ripening process peel color of persimmon fruits. This is very clear as peel color measurements in hue angle after 4 weeks were too close to each others and lying in the range of $48.9^{\circ}-50.46^{\circ}$, corresponding to the yellow with slight brownish coloration. This may be due to the effect of ethylene emitted from of fruits during cold storage and pushing fruit tissue towards complete ripening (Bower $e t$ al., 2003).

Table (9): Effect of treatments on peel color of "Costata" persimmon (hue angle degree) in the $2^{n d}$ season.

\begin{tabular}{|c|c|c|c|}
\hline Treatment & $\begin{array}{c}\text { After } \\
\text { 2 weeks }\end{array}$ & $\begin{array}{c}\text { After } \\
\text { 3 weeks }\end{array}$ & $\begin{array}{c}\text { After } \\
\text { 4 weeks }\end{array}$ \\
\hline Ascobin & 75.91 & 54.14 & 49.95 \\
\hline GA $_{3}$ & 85.52 & 52.84 & 48.82 \\
\hline Glycine & 67.9 & 52.18 & 49.35 \\
\hline Chitosan & 64.82 & 51.76 & 50.46 \\
\hline Azolla & 69.18 & 54.73 & 49.76 \\
\hline Yeast & 64.36 & 54.62 & 49.16 \\
\hline Kaolin & 61.04 & 54.82 & 48.9 \\
\hline Control & 73.02 & 53.36 & 49.77 \\
\hline
\end{tabular}

\subsection{Effect of the treatments on eating quality after cold storage}

It is evident from Table (10) the all the fruits by end of storage had acceptable eating quality but fruits tested from treatment of yeast had the best taste in both seasons (excellent grade) followed by fruits of Azolla treatment (very good) and this was consistent with their high content of T.S.S. \% and low content of tannins especially by the end of cold storage. Fruits of Chitosan and Kaolin treatments had a very good

Table (10): Effect of treatment on the eating quality of Costata persimmon fruit after cold storage

\begin{tabular}{|c|c|c|c|}
\hline \multirow{2}{*}{$\begin{array}{c}\text { Treatment } \\
\text { Ascobin }\end{array}$} & $\begin{array}{l}\text { Average of } \\
\text { taste } 1^{\text {st }} \text { year }\end{array}$ & \multicolumn{2}{|c|}{$\begin{array}{l}\text { Average of } \\
\text { taste } 2^{\text {nd }} \text { year }\end{array}$} \\
\hline & (6.3) good & $(6.0)$ & good \\
\hline $\mathbf{G A}_{3}$ & good & $(5.5)$ & good \\
\hline Glycine & $(6.2)$ & $(6.0)$ & good \\
\hline Chitosan & (7.9) v. good & $(7.6)$ & V. good \\
\hline Azolla & (8.0) v. good & $(8.3)$ & V. good \\
\hline Yeast & \begin{tabular}{|ll} 
(9.0) & Excellent \\
\end{tabular} & $(8.9)$ & Excellent \\
\hline Kaolin & (8.0) v. good & $(8.0)$ & V. good \\
\hline Control & good & $(5.8)$ & good \\
\hline
\end{tabular}

taste and other treatments including the control came lastly with acceptable good tasted, but the control eating quality was inferior as it had the highest percentage of tannins.

\section{Conclusion}

Biostimulants used in the current experiment on persimmon trees had a positive variable effects on yield parameters and fruit quality of "Castata" persimmon fruit. Ascopin treatment improved fruit set percentage and fruit shape index. GA3 treatment gave higher fruit set, number of fruits, fruit firmness, shape index, TSS and TSS/acid ratio as well as reduced acidity. Citosan effectively increased fruit yield, number, weight and dimensions. Yeast was effective in increasing fruit quality and decreasing fruit tannins content. Also, Kaolin treatment induceding fruit set and diameter. Throughout cold storage at $4{ }^{\circ} \mathrm{C}$ and $90 \% \mathrm{RH}$ for 4 weeks, GA3 treatment helped persimmon fruits to maintain firmness and decrease fruit acidity. Yeast was the most effective treatment to decrease fruit tannins and acidity throughout storage as well as to improve vitamin C content, TSS and fruit taste. Kaolin treatment increased vitamin C content and peel color while decreased fruit weight loss through storage. It is recommended to use anyone of this group of biostimulants in persimmon farms, and it is preferable to use yeast as a cheap, and available material to get better quality fruits.

\section{REFERENCES}

Ahmed S., Mohammed A., Zahid H., Raheel A. and Thompson A.K. (2007). Effect of fruit size and treatments in the shelf life and quality of ripe banana fruit. Sarhad. J. Agric., 23 (1): 46 - 54.

Aly M. Abd El-Megeed N. and Awad R. (2010). Reflective particle films affected on sunburn, yield and mineral composition of fruit maturity of " Anna " apple trees. Res. J. Agric. Biol.Sci., 6 (1): 84 - 92.

A.O.A.C. (Association of Official Agricultural Chemists) (1990). Official methods of analysis $15^{\text {th }}$ Ed. Washington D.C. USA.

Arpita A., Das Subroto, Bhattacharyya P. and Bandyopadhyay B. (2010). Inhibition of polyphenl oxidase in banana, apple and mushroom using different antibraining agents under different condition. Int. J. Chem. Sci. 8 (5). 550 - 558.

Arnol L. and Del-Rio M.A. (2004). Quality of persimmon fruit $\mathrm{CV}$. Rojo brilliant during 
cold storage. Spanish J. Agric. Res. , (2) 2 : $243-417$.

Attala E.S., El-Segeni A.M. and Eliwa G.I. (2000). Response of Le-Conte pear trees to foliar applications with active dry Yeast. J. Agric. Sci. Mansoura. Univ., 25 (12): 8005 - 8011.

Ben-Arie R., Bazak H. and Blumenfeld A. (1986). Gibberellin delays harvest and prolongs storage life of persimmons fruits. Acta Hort., (179): 807-813.

Ben Arie R., Saks Y., Snego L. and Frank A. (1996). Cell wall metabolism in gibberellin treated persimmon fruit. Plant Growth Regulation, 19 (1): 25 - 33.

Bower J.H. , iasi W.V. and Mitcham E. J. (2003). Effect of ethylene in the storage environment on quality of Bartlett pears. Postharvest ,Biol. Tech., (28): 371 - 379 .

Burme L., Moallemi N.O. and Martazavi S.M. (2011). Anti transpiration effect of Kaoline on some physiological traits of olive cultivars. J.of Crop Produc. and Process . 1(1) ISF. Univ. Technol., I SF. Iran.

Cheriot S., Billand C., Maillasd MN, Nicolas J. (2007). Inhibition of polyphenoloxydase activity by mixtures of heated cysteine derivatives with carbonyl compounds. Mol. Natr. Food Res., 51 (4): 395 - 403.

Du J., Gemma H. and Iwahor S. (1998). Effect of chitosan coating on the storability and on the ultrastructural changes of "Jonagold" apple fruit in storage. Food Preserv. Scie., 24 (1): 23 - 29.

El-Badawy H. E. (2007).Trails to improve marketing characteristics and prolonging storage life of persimmon and Mango fruits PH.D. Thesis faculty of Agriculture, Benha University. Benha, Egypt.

El-Gaouth A., Arul J., Grenier J. and Asselin A. (1992). Antifungal activity of chitosan on two postharvest pathogens of strawberry fruits. Phytopathol., (82): 398 -402 .

Eissa F.M., Fathi M.A. and Yehia M.M. (2003). Response of Canino apricot to foliar application of some biostimulants. Minia J. Agric . Res. Develop., 23 (1) 69-81.

Eliwa G.L., Wally A.S.M. and Ali M.M. (1998). Effect of calyx sepal removal gibberellic acid spraying on Costata persimmon fruit characteristics. J. Agric. Sci. Mansoura . Univ., 23(2): 831- 841.

Ergun M. (2012). Postharvest quality of Galaxy apple fruit in response to Kaolin- based particle film application. J. Agr. Sci. Tech., (14): (599-607).

Ezz T.M., Aly M.A. and Awod R.M. (2012). Storage ability of mango fruit improvement by some natural preharvest applications. Athens ATINERS conference paper series no. Agr., 0238.

Fathi M.A., Mohamed-Azza I. and Abd-El-Bary A. (2011). Effect of Sitofex (CPPU) and GA3 spray on fruit set, fruit quality, yield and maturity value of Costata Persimmon. Nat. and Sci. 9 (8): 40-49.

Fayek M.A., Yehia T.A., El-Fakhrany E.M.M and Farag, A.M. (2011). Effect of ringing and amino acid application on improving fruiting of Le Conte trees. J. Horti. Sci. ornament. Plants, 3(1): 01-10.

Ibrahimm H., Ahmed I.M., Mohamed Y. and Ahmed, F.F. (2007). Relation of fruiting in Hindy Bisinara mangos to foliar nutrition with $\mathrm{Mg}, \mathrm{B}$ and $\mathrm{Zn}$ and some antioxydants. African Crop Science Conference Proceedings. Vol.( 8): 411 415 (El Minia), Egypt.

Ismail F., Wahdan H. M., M.T. and El-Sheikh A.F. (2003). Response of Thompson seedless and Roumi Red grape cultivars to foliar sprays with yeast extract and GA3. J. Agric. Sci. Mansoura Univ. Egypt 28: 6321- 6334.

Jacqueline V.T.U., Grabriela P.F., Gabriela M.G. and Ricardo, A. K. (2014). Chitosan application pre or postharvest prolong raspberry shelf life quality. Postharvest Biol. Tech., 91:(72 - 77).

Jianglian D. and Shaoying, Z. (2013). Application of Chitosan Based Coating in Fruit and Vegetable preservation A Review. J. Food process. Technol., 4 (5): 277.

Kabeel H. (1999). Effect of some growth regulators on fruit set, yield and fruit quality of " Costata " persimmon trees. Minufiya. J. Agric. Res., 24 (5): 1727 1739.

Kassem H.A., El-Kobbia A. M., Marzouk, H. A. and El-Sebaiey M.M. (2010). Effect of foliar sprays on fruit retention,quality and yield of Costata persimmon trees. Emir. J. Food Agric., 22 (4): 259 - 274.

$\mathrm{Li} \mathrm{H}$. and $\mathrm{Yu}$ T. (2000). Effect of chitosan on incidence of brown rot, quality and physiological attributes of postharvest 
peach fruit. J. Sci. Food Agric., 81. 269 274.

Mansour A.E.M. (1998). Response of Anna apples to some biofertilizers. Egypt. J. Hort., 25 (2): 241 - 251.

Mansour A.E.M., El-Shammaa M.S., Shaaban E. A. and Maksoud M.A. (2010). Influence of some antioxidant on yield and fruit quality of four mango cultivars. Res. J. Agric.and Biol. Sci., 6 (6): 962 - 965.

McGuire R.G. (1992). Reporting of objective color measurements. Hort Sci.. 27(12). 606-609.

Ministry of Agric. Egypt (2013). Annual Report, Economic Statistics.

Mohamed A. I., Fathi M. A. and Mikhael, G. B. (2012). Effect of foliar application with some biostimulants on vegetative growth, chemical content, yield and fruit quality of "Costata" persimmon. J. Biol. Chem. Environ. Sic., 8 (1): 481 - 506.

Mohamed H. M., Al-Kamar F. A. and Abd-El-All A. A. M. (2013). Effect of magnetite and same biofertilizes application on growth and yield of Valencia orange trees under ElBuston condition. Nature and Sci., 11 (6): 46 -61 .

Nasr M. M., Mohamed S A. and Michael B. (2009). Effect of some compounds on fruit yield, fruit quality and storability of Le-Cont pear. Journal Biol. Chem. Environ. Sci., 4 (1): 985 - 1012.

Ramin N. and Tabatabie F. (2003). Effect of various maturity stages at harvest and storability of persimmon fruits. J. Agric. Sci. Tech. (5): 113 - 123.

Rao-Chandra G. (2015). Engineering for storage of fruits and vegetables cold storage. Academic Press (p.p. 26 - 28).
Shabriar S. (2013): Inhibitory effect of cysteine and glycine upon portial pusified pdypheral oxidese of Pyrus Communes. European J. exp. Boil., 3(6): 476 - 483.

Snedecor G.W. and Cochran W.G. (1972). Statistical Methods. $6^{\text {th }}$ ed. The Lowa State Univ. Press. Lowa, U.S.A. p. 593.

Takashi A., Yasuhiko S., Ayako I., Hiroshi K., Toshiyuki T., Fumiaki N. and Keizo Y. (2010). Condensed tannin composition analysis in persimmon (Diospyros Kaki Tnunb.) fruit by acid catalysis in the presence of Excess Phloroglucinol. J. Japan. Soc. Hort. Sci. 79 (3): $275-281$.

Venkataraman G. S. (1981). Blue Green Algae for rice production. FAO Soil Bull., No. 46, Rome, Italy.

Wagner G.M. (1997): Azolla, a review of its biology and utilization. Bot. Rev. 63. (1 - 26).

Waller A. and Duncan D.B. (1969). Multiple range and Multiple test. Biometrics, 11: 1 - 24.

Wally A.S.M., Mokhtar H. and El-Fakharany E.M. (1999). Effect of Biozyme and Gibberellic acid on fruit set, yield and fruit characters of "Costata" persimmon. Egypt, J. Agric. Res., 77 (2): 805 - 815.

Wand S.J.E. , Thero K.I., Ackerman j. Marais S.J.S. (2006). Harvest and post-harvest apple fruit quality following applications of kaolin particle film in south African orchards. Sci. Hort., $107: 271$ - 276.

Winton A. and Winton, M. (1958). The analysis of foods. John Willey and Son, Inc. London, UK. 853 - 867.

York R. and Marshall S. (2003). Physicochemical properties and function of plant polyphenol oxidese. A review. J. Food bioch., 27: 361 422. 
تأثير بعض المنشطات الطبيعية على العقد والمحصول وجودة الثمار عند الحصاد

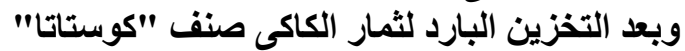

حدي الزيات - نيفين مصطفى طه - نجلاء حسين شقوير - جيهان عبد الملك الحديدى

$$
\text { معهد بحوث البساتين- مركز البحوث الزر اعية ـ الجيزة ـ مصر }
$$

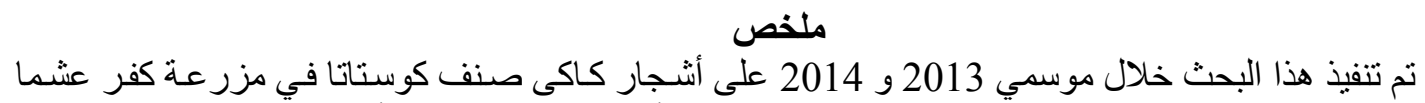

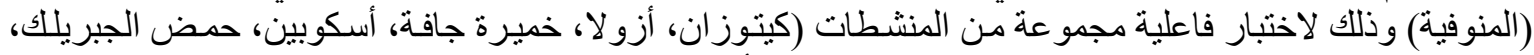

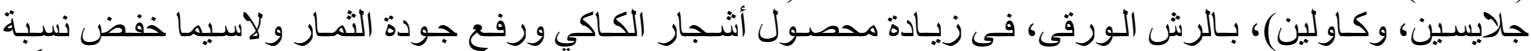

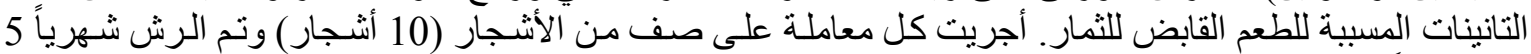

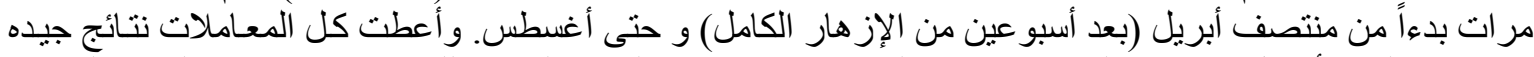

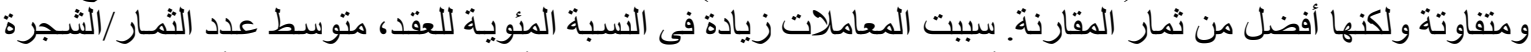

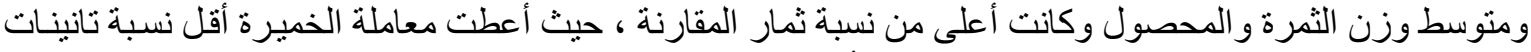

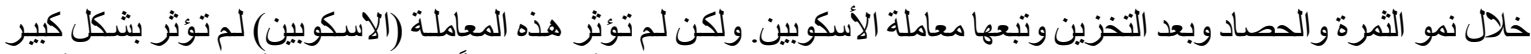

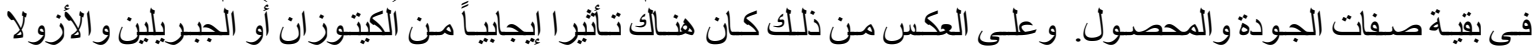

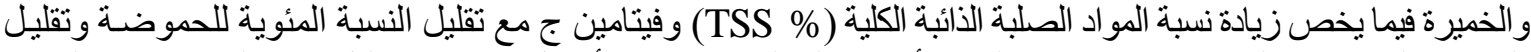

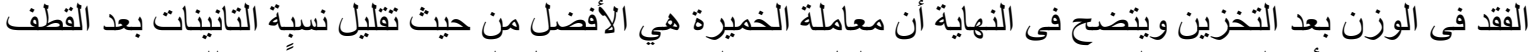

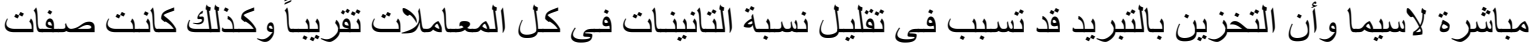

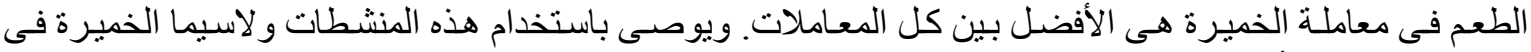

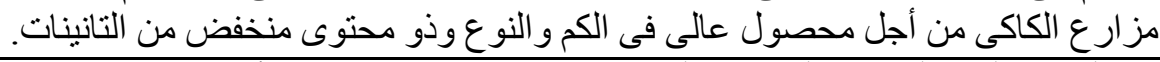

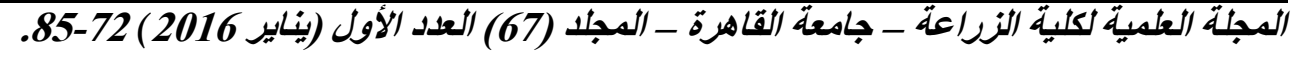

